\title{
Productivity and economical appraisal of growing raspberry according to substrate for mulching under the conditions of podilia area in Ukraine
}

\author{
H. V. Pantsyreva ${ }^{1 *}$, R. O. Myalkovsky ${ }^{2}$, I. A. Yasinetska ${ }^{2}$, V. M. Prokopchuk ${ }^{1}$ \\ ${ }^{1}$ Vinnytsia National Agrarian University, 3, Soniachna Str., Vinnytsia, Ukraine, 21008 \\ ${ }^{2}$ State Agrarian and Engineering University, 13, Shevchenko Str., Kamianets-Podilskyi, Ukraine, 32300 \\ E-mail: pantsyreva@vsau.vin.ua \\ ORCID: https://orcid.org/0000-0002-0539-5211, Researcher ID: L-5102-2018
}

Received: 05.02.2020 Accepted 05.03.2020

\begin{abstract}
Based on studies of substrates for mulching raspberry varieties Veresnevi zori revealed the following: for mulching with straw or sawdust, the onset of the phenological phases of raspberry plants occurs later, compared to the cultivation without mulching; a greater number of root shoots and shoots are provided by growing raspberries without mulching, but a higher shoot height (133.2 $\mathrm{cm}$ ) and shoot shoots $(123.9 \mathrm{~cm})$ distinguishes the straw mulch variant; the maximum yield of raspberry berries of the Veresnevi zori variety is provided by mulching with sawdust - $94.5 \mathrm{c} / \mathrm{ha}$, which is $3.1 \mathrm{c} /$ ha more than straw mulching and by $16.9 \mathrm{c} / \mathrm{ha}$ the control variant. The share of ripe berries in the yield by mulching sawdust increases to $81.5 \%$, which is $4.4 \%$ more compared to straw mulching and $9.1 \%$ more compared to the control variant; the highest average weight of berries and maximum weight of 5 berries was obtained by mulching raspberries with sawdust; for raspberry mulching with sawdust, the profitability of raspberry berries production is the highest $-258.9 \%$ and $4.3 \%$ less than straw mulching. The results of the work are recommended to be used during research and in practice.
\end{abstract}

Key words: Raspberry; Variety; Yield; Mulching substrate; Economic efficiency

\section{Introduction}

Raspberry is an early-maturing and high-yielding culture. By cultivating it on a highly qualified agrotechnical background, taking into account all the properties in general and each sort in particular, today we can reach the yield of 20-25 tons per 1 hectare (4-5 kg from the bush) (Burmistrov A. D., 1985, Mazur V.A., 2018). Depending on the sort and conditions of cultivating the fruits of raspberry contain $7-11 \%$ of sugars (among which fructose and glucose are pervading), $0,5-0,8 \%$ of proteins, $0,6-0,9 \%$ of pectin, $1,2-2.3 \%$ of organic acids. Among the last, a special place is taken with salicylic acid. It is differing with its antibacterial properties and is used as a diaphoretic, pyretic and analgesic resource (Barabash O.Yu., 2000; Pantsyreva, H.V., 2019, Mazur V.A., 2018). The annual need of a man in the application of raspberry berries is about $4 \mathrm{~kg}$ (Burmistrov A. D., 1995, Dmitrieva L., 2018, Mazur V.A., 2018). In 2019, the total area of raspberry plantations in Ukraine was 6.3 ths. hectares, in particular, the fruit-bearing -5 ths., the total harvest -30.3 ths. tons, the yield -6 ton per hectare. However, the level of industrial production of raspberries fruit is low for the full provision of the population with highly-marketable competitive products, because the agricultural part takes only $5 \%$ of the total extent. The priority in the cultivation of this culture in Ukraine has Vinnytska, Kievska, Cherkaska, Kropyvnytska regions and regions with a well developed retreating industry.

\section{Materials and Methods}

The researches of studying raspberry economical appraisal in agrocoenosis were conducted in 2018-2019 on the research field of the Vinnytsia National Agrarian University. Gray forest soils, medium loam soils are characterized with the following elements: humus content is medium (2.4\%), $\mathrm{P}_{2} \mathrm{O}_{5}(271.2 \mathrm{mg} / \mathrm{kg})$ and $\mathrm{K} 2 \mathrm{O}(220.0 \mathrm{mg} / \mathrm{kg})$ provision is very high. The soil acidity of is close to neutral. During the research, $3 \times 0.5 \mathrm{~m}$ planting scheme was worked out, every variant was in three reduplications for 12 plants in each. The object of research was a raspberry sort of the Veresnevi zori. The remontant sort of the National Agrarian University selection, received by crossing in 1988 the remontant sorts of Babyne Lito and Zieva by the breeders P.Z. Chernov, V.T. Gontar, A. P. Dusheyko, a strong-growing bush, straight branches with bent tops, sprouts are thick and medium thick, in summer they are green with wax scurf, in autumn they are reddish-brown and form of 15-20 fruit branches (laterals) on every bush.

Root sprouts are formed on the average 19, and offsprings replacement - 10 pcs. with height, respectively, 140 and $148 \mathrm{~cm}$. Standard seedlings are up to $51 \%$ of the root sprouts number with a well-developed root system. It is one of the earliest remontant raspberries sorts. Autumn harvest berries begin to ripen on August 12-15, which is in 3-5 days earlier than the control sort of Babyne Lito. When growing berries to get only autumn harvest, they ripen for $60-70 \%$, but summer and autumn $-50-60 \%$. The high-yield, average yield for $1999-2001$ of the autumn harvest is 84.6 centners per hectare or $24.8 \mathrm{c} /$ hec more than the total yield (summer and autumn) and 28.3 centners per hectare more than autumn yield of the sort Babyne Lito. Berries are large, the average weight is $3.5 \mathrm{~g}$, and the maximum is $4.5 \mathrm{~g}$ during tasting characterization of the fresh berries of the autumn harvest 4.4 
points. They contain $9.1 \%$ of dry substances, $5.7 \%$ of sugars, $2.1 \%$ of organic acids, $44 \mathrm{mg} / 100 \mathrm{~g}$ of vitamin C. Plants of the Veresnevi zori sort are slightly freezing, mainly the top parts of the branches with laterals that have fructified in autumn. They are weakly affected (0.8 points) with purple spots and with anthracnose (Dusheyko A. P., 2003, Bounous D., 1986). The raspberries of 2008 planting year were used in the researches. The scheme of planting was $3 \mathrm{~m} \times 0,5 \mathrm{~m}$. Every variant was in three replicates for 12 plants in each. Hereafter, the lines of plants were formed in the width of $50-60 \mathrm{~cm}$. The care about the plants was realized according to generally accepted recommendations (Dmitrash O.I., 1999, Banshy S., 1986). The mulching with straw and sawdust was carried out in the first days of the April first decade.

The following records and observations were done for the purpose of determining the best variants:

1. Calendar periods of phenological phases: the beginning of growth of radical offsprings and radical sprouts, the blooming, berries ripening.

2. For accounting the total yield, the yield from 1 meter of the line was taken into account and it was counted per hectare of the area. Harvesting and accountings were realized mainly in 2-3 days (Moiseychenko V. F., 1992).

3. The economical effectiveness of the variants was estimated by defining the magnitude of production expenditures, prime cost of production and cost prices, the income received from the sales and the level of profitability (Shestopal O. M., 2002, Mazur V.A., 2018).

Field, statistical and laboratory methods of research were used during the experimental work.

The harvest accounting of remontant sorts was started in the year of planting, and accounting of ordinary sorts - from the next year after planting. The fruits were harvested with the intervals from one to two days. The selection of examples and the analytical researches of the main organic substances content in berries were done in accordance to the methodological recommendations for realizing researches on the storage and processing (1980). The coefficient of stability on the basis of fruiting was calculated according to the formula developed by V.I. Kashin (1999), and the index of standart of raspberry sorts - according to the methodology proposed by O.I. Tarashvvili (1987). The remontant of sorts were determined with the length of the autumn fruiting zone of the offspring, with the total length of the laterals on it and with the number of ripe berries (from the total number of generative units). The economical appraisal of raspberries was carried out according to the "Methodology of the economical and energy appraisal of plantings types, sorts, investments in the main capital, innovations and results of technological researches in horticulture" (2006). Statistical processing of the data was carried out using the methods of dispersion and correlation analysis with the works of B.O. Dospekhov (1985) using the computer program "Agrostat" and Microsoft Excel software.

\section{Results and Discussion}

The passage of phenological phases by the plants depends on the biological characteristics and climatic conditions of the zone. Our research has established the dependence of the phenological phases of the raspberry Veresnevi zori from the substrate for bankingup and the climatic conditions of the research zone. So, in 2018, the beginning of root offspring growth in the control variant of plants fell on 7.04., mulching with straw the growth of root offsprings began 2 days later. And, the root offsprings began to grow the last with mulching with sawdust - 15.04, which, respectively, is 6 and 4 days later than the control variant and mulching straw (Table 1).

Table 1. The phonological phases of the growth and the development of Veresnevi zori raspberry sort depending on the substrate for mulching (average for 2018-2019 pp.).

\begin{tabular}{|c|c|c|c|c|}
\hline \multirow{2}{*}{$\begin{array}{c}\text { The substrate for } \\
\text { mulching }\end{array}$} & \multicolumn{2}{|c|}{ The start of growing } & \multirow{2}{*}{$\begin{array}{l}\text { The start of } \\
\text { blooming }\end{array}$} & \multirow{2}{*}{$\begin{array}{c}\text { The start of } \\
\text { berries ripenning }\end{array}$} \\
\hline & $\begin{array}{c}\text { Root } \\
\text { offsprings }\end{array}$ & $\begin{array}{l}\text { Sprouts of } \\
\text { replacement }\end{array}$ & & \\
\hline Without mulching (c) & 9.04 & 28.04 & 14.06 & 15.07 \\
\hline Straw & 11.04 & 30.04 & 15.06 & 17.07 \\
\hline Sawdust & 15.04 & 4.05 & 21.06 & 22.07 \\
\hline
\end{tabular}

\section{C- Control.}

Blooming in the studied variants began in the second decade of June. So, the beginning of blooming of the plants of the control variant fell on 14.06, which, respectively, is 1 and 7 days earlier than with mulching with straw and sawdust. The latest were the plants with sawdust mulching which began to blossom on 21.06. The same regularity has been observed for the berries ripening. The berries from the plants of the control variant were the first to ripen -15.07 , which were 2 and 7 days earlier, than with straw and sawdust mulching. At the latest, the phase of berry ripening was the last recorded in plants with sawdust mulching -22.07 , which is 5 days later, than with straw mulching. Reproductive ability characterizes the potential to reproduction of the sort. It depends on the biological peculiarities and conditions of growing. The effect of substrates in mulching on the number and height of raspberries of the Veresnevi zori sort was established with a help of the researches (Table 2). So, in 2018, the highest number of root offsprings was recorded in plants from the control variant areas $-18.3 \mathrm{pcs} . / \mathrm{m}$, which is $1.6 \mathrm{pc}$. more than with straw mulching and $2.8 \mathrm{pc}$. more than with sawdust the mulching. The lowest number of root sprouts was received from the sawdust mulching. The same regularity was observed in 2019. So, the maximum number of roots sprouts was $20.2 \mathrm{pcs} / \mathrm{m}$ fixed in the control version. With the straw mulching, the value of showings was decreased in 0.8 pcs., but with straw mulching - in 1.3 pcs., in comparance to control.

Table 2. The root sprouts characteristic of raspberry of Veresnevi zori sort depending on the substrate for mulching.

\begin{tabular}{lccccccc}
\hline \multicolumn{1}{c}{$\begin{array}{c}\text { The substrate for } \\
\text { mulching }\end{array}$} & \multicolumn{3}{c}{ Number, pcs./m lineal } & \multicolumn{3}{c}{ Height, sm } \\
Without mulching (c) & $\mathbf{2 0 1 8}$ & $\mathbf{2 0 1 9}$ & average & $\mathbf{2 0 1 8}$ & $\mathbf{2 0 1 9}$ & average \\
Straw & 18,3 & 20,2 & 9,3 & 116,5 & 124,8 & 120,7 \\
Sawdust & 16,7 & 19,4 & 18,1 & 121,4 & 130,5 & 126,0 \\
C & 15,5 & 18,9 & 17,2 & 127,1 & 139,3 & 133,2 \\
\hline
\end{tabular}


It has been established that over the years of researches the maximum number of root sprouts has a control variant - $19.3 \mathrm{pc} / \mathrm{m}$ lineal, which significantly outstrips the rest of the studied variants. Somewhat inverse dependence wass noted for the height of root sprouts. So, in 2018, the minimum value of the index was noted for the cultivating of The Veresnevi zori raspberry sort without mulching were $116.5 \mathrm{~cm}$. The straw mulching contributed to an increase of the height of root sprouts: the value of the indicator increased to $4.9 \mathrm{~cm}$, in comparison with the control variant. The root sprouts were the highest on the areas mulched with sawdust. The same regularity was observed in 2019 . The lowest height of root sprouts was noted for the control variant $-124.8 \mathrm{~cm}$, and with straw or sawdust mulching, the height of the sprouts increased, respectively, in 5.7 and $14.5 \mathrm{~cm}$. In the current year, the height of the root sprouts has increased, in comparison with 2018 in the control variant - in $8.3 \mathrm{~cm}$ and 9.1 and $12.2 \mathrm{~cm}$, respectively, with straw and sawdust mulching. It has been proved that during the years of the researches (2018-2019) the maximum height of raspberry root sprouts of the Veresnevi zori sort was $133450 \mathrm{~cm}$ in the variant with sawdust mulching, which is in 7.2 and $12.5 \mathrm{~cm}$ more in comparison with the straw mulching and control variant. Such a difference, probably, can be explained with the creation of more advantageous conditions for the growth of sprouts with preventing water evaporation.

The yield depends on a number of factors, in particular, the biological characteristics of the sort, soil and climatic conditions, the level of agricultural technology, etc. The research has established the influence of the substrate for hilling on the yield of raspberry the Veresnevi Zori sort (Table 3). So, in 2018, the minimum yield had a control variant. The value of the indicator increased significantly with straw mulching - to 16.2 centners per hectare, in comparison with the control variant. The maximum yield was obtained with sawdust mulching $-93.4 \mathrm{c} /$ ha, which pervades over the rest of the studied variants significantly. The same regularity was observed in 2019. The lowest yield was recorded for cultivating raspberry of the Veresnevi Zori sort without mulching - 75.7 centners/ha, which is in 17.6 and 19.9 centners/ha less, compared with straw and sawdust mulching.

Table 3. The raspberry yield of Veresnevi Zori sort depending on the substrate for mulching. (average for 2018-2019).

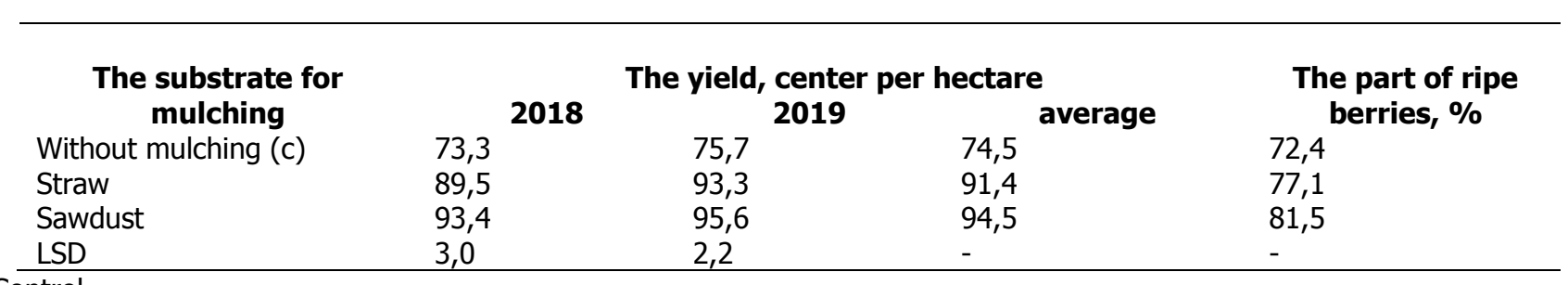

C - Control.

In 2019, there was an increase of the raspberries yield of the Veresnevi Zori sort, in comparison to the previous year. Thus, in the current year, the yield of the control variant increased to $2.4 \mathrm{c} / \mathrm{ha}$, by $3.8 \mathrm{c} / \mathrm{ha}$ - with straw mulching and to $2.2 \mathrm{c} / \mathrm{ha}-$ with sawdust mulching. Generally, over the years of researches, the maximum of raspberry yield of Veresnevi Zori sort has been provided with sawdust mulching 94.5 centners per hectare, which predominant straw mulch in 3.1 per cent per hectare and a control variant in 16.9 centners per hectare. The part of ripe berries in the yield of the control variant was minimal $-72.4 \%$ and significantly increased with straw mulching. The maximum part in the yield of ripe berries had the variant, which was mulched with sawdust $-81.5 \%$, which is in $4.4 \%$ more in comparison to straw mulching and in $9.1 \%$ more in comparison with the control variant. According to the average data, the lowest average weight of a berry was received from cultivating raspberry of the Veresnevi Zori sort without mulching $-3.0 \mathrm{~g}$, which is in 0.1 and $0.4 \mathrm{~g}$ less, compared with the variant with straw and sawdust mulching (Figure 1). The maximum value of the analyzed indicator was a variant with sawdust mulching: the average weight of a berry was $3.4 \mathrm{~g}$, whereas for straw mulch the value of the indicator decreased in $0.3 \mathrm{~g}$.

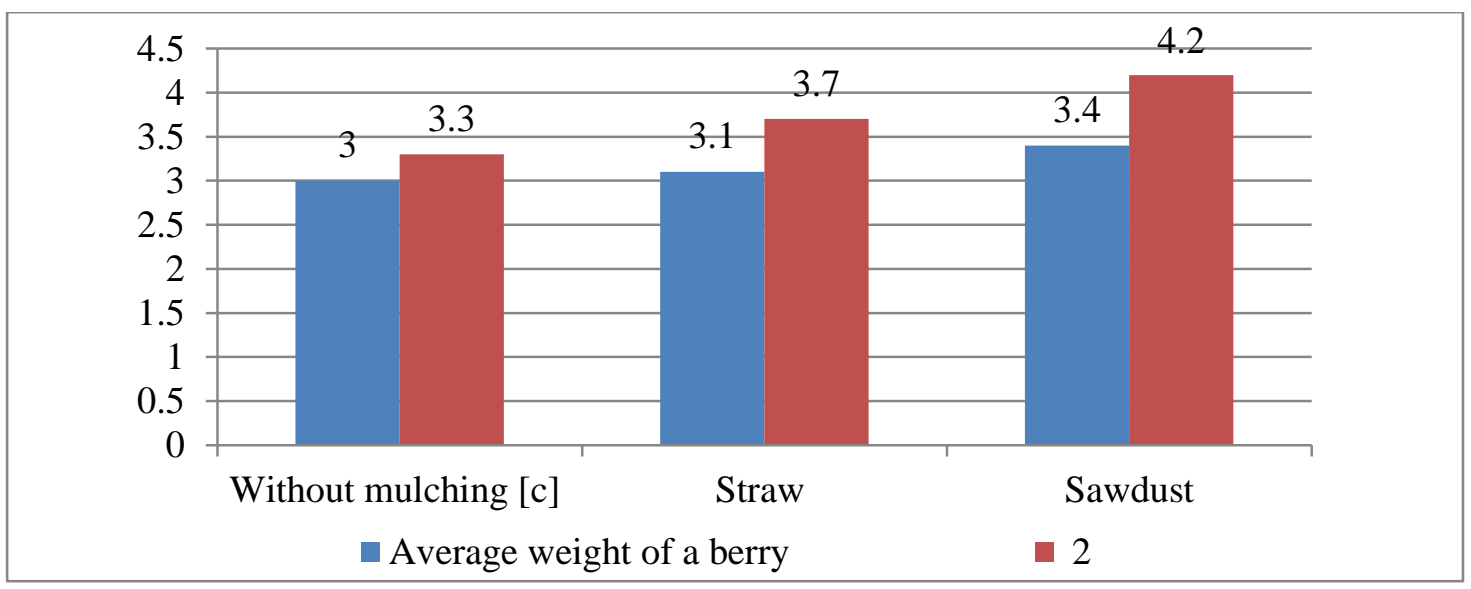

C - Control.

Figure 1. The weight of a raspberry berry of Veresnevi Zori sort depending on the substrate for mulching, $g$ (average for 2018 2019).

There was established an influence of substrates on the hilling of the maximum weight of raspberry of the Veresnevi Zori sort. Thus, the smallest value of the analyzed index was recorded for growing raspberry without mulching $-3.3 \mathrm{~g}$ and in 0.4 and $0.9 \mathrm{~g}$ more, respectively, for straw and sawdust mulching. The main indicators of economic appraisal of fruit-bearing crops plantations are: the profit from 1 hectare of a garden, a berry land, the prime cost and the level of profitability of fruit production. The economical efficiency of fruit-bearing production is formed firstly depending on the ratio of profits to the operating costs of its production, to the prime cost. The amount of the profit depends on the prime cost and the price of its implementation. At the same time, on the cost of fruit and berries directly affects two of these components: the extent of operating costs and yields of plantations. And the selling 
price of products depends on its quality and market conditions. The economic appraisal of the substrates application for raspberry mulching of the Veresnevi Zori sort was carried out on the basis of "Methodology of economic and energy appraisal of types of fruit and berry plantations, pomological sorts and results of technological research in horticulture" (Shestopal O.M., 2002).

According to the methodology of economic appraisal of research results, the following indicators were defined: operating costs per 1 hectare, UAH; prime cost of 1 centner of berries, UAH; the yield of berries, c/ha; selling prices 1 centner of berries, UAH ( $900 \mathrm{UAH}$ /cent); the profit from 1 hectare of plantings, $\mathrm{UAH}$; and the level of profitability of their production, \%. Among the studied variants the maximum profit had the variant with sawdust mulching the raspberry of Veresnevi Zori sort - UAH 61350, which is in UAH 2290 more, than the variant with straw mulching and $15900 \mathrm{UAH}$ more in comparison to the control variant (Table 4). The smallest profit provided a control variant - UAH 45,450. The prominent increase of the indicator (13610 UAH), compared with control variant, was provided with the straw mulching of raspberries.

Table 4. The economical appraisal of growing the raspberries of Veresnevi Zori sort depending on the substrate for mulching (average for 2018-2019).

\begin{tabular}{|c|c|c|c|}
\hline The indicator & Without mulching (c) & Straw & Sawdust \\
\hline Output cost for 1 hectare, UAH. & 21600 & 23200 & 23700 \\
\hline Yield of berries, cent/hectare & 74,5 & 91,4 & 94,5 \\
\hline $\begin{array}{l}\text { Prime cost per } 1 \text { cent of beeries, } \\
\text { UAH. }\end{array}$ & 289,9 & 253,8 & 250,8 \\
\hline $\begin{array}{l}\text { The cost of production from } 1 \\
\text { hectare in prices of sales, ths. } \\
\text { UAH. }\end{array}$ & 67,05 & 82,26 & 85,05 \\
\hline $\begin{array}{l}\text { The profit from } 1 \text { hectare of } \\
\text { plantings, UAH. }\end{array}$ & 45450 & 59060 & 61350 \\
\hline The level of profitability, \% & 210,4 & 254,6 & 258,9 \\
\hline
\end{tabular}

C - Control.

The highest level of profitability of raspberry berries production- 258,9\%, was provided with sawdust mulching. The profitability of berries with straw mulching was only in 4,3\% lower. The minimal index of analyzed indicator was received from growing the raspberry of Veresnevi Zori sort without mulching. So, an analysis of the economic efficiency of growing raspberries, depending on the mulch substrate, has shown that traditional cultivation technology does not provide a maximum profit, while straw or sawdust mulching is more effective.

\section{Conclusions}

On the basis of researches of substrates for mulching the raspberry of Veresnevi Zori sort the following points were set:

1. For mulching with straw or sawdust, the beginning of the phenological phases of the raspberry plants occurs 1-6 days later, in comparison to cultivation without mulching.

2. A greater number of root offsprings and sprouts of replacement is provide with the cultivation of raspberry without mulching, but with a higher height of offsprings $(133.2 \mathrm{~cm})$ and sprouts of replacement $(123.9 \mathrm{~cm})$ has a variant with straw mulching.

3. The maximum yield of raspberry berries of the Veresnevi Zori is provided with sawdust mulching - is 94.5 centner per hectare, which predominates straw mulching in 3.1 centner/hectare and a control version in 16.9 centner per hectare. The part of ripe berries in the harvest with sawdust mulching increases to $81.5 \%$, which is in $4.4 \%$ more than in the variant with straw mulching and is in $9.1 \%$ more than in the control variant.

4. The highest average weight of berries $(3.4 \mathrm{~g})$ and maximum berry weight $(4.2 \mathrm{~g})$ was received with sawdust mulching of raspberry.

5 . The level of the production of raspberry berries profitability is maximal $-258.9 \%$ with the sawdust mulching, and is in $4.3 \%$ lower than with straw mulching.

\section{References}

Burmistrov A. D. (1985). Berry cultures/A. D. Burmistrov. Leningrad: Agropromizdat, 275 p.

Barabash O. Yu. (20008). Raspberry // Vegetable and fruit-growings: Textbook/[Barabash O.Yu., Tsiz O.P., Leontiev O.P., Gontar V.T.]. - K .: Higher school. P. 482-485.

Burmistrov A. D. (1995). Berry cultures/A.D. Burmesters. L.: Agropromizdat, 115 p.

Dusheyko A. P. (2003). Economic-biological appraisal of new and perspective sorts of raspberries in the conditions of the foreststeppe in Ukraine: Dis. Cand. ag.-cult. sciences: 06.01.07/National Agrarian University. K., 162 p.

Dmitrieva L. (2018). The ripe raspberries and the prospects of the Alpine strawberries/L. Dmitrieva // Fruit-and-vegetable growing. July-August. P. 45-47.

Dmitrash O.I. (1999). Growing of remontant raspberries to extend the term of consumption of fresh berries/O.I. Dmitrash, V.S. Markovsky // Gardening: interagency thematic scientific collection. - K.: Harvest, 48. P. 88-94.

Moiseychenko V.F. (1992). Fundamentals of scientific research in fruit growing, vegetable growing, grapes growing and picking technologies for fruit and vegetable production/V.F. Moiseychenko - K.: NVK VO, 364 p.

Mazur, V.A., Didur, I.M., Pantsyreva, H.V., Telekalo, N.V. (2018). Energy-economic efficiency of growth of grain-crop cultures in the conditions of right-bank Forest-Steppe zone of Ukraine. Ukrainian Journal of Ecology. Volume 8. № 4, 26-33.

Mazur V. A., Didur I. M., Pantsyreva H. V., Telekalo N. V. (2018). Energy-economic efficiency of growth of grain-crop cultures in the conditions of right-bank Forest-Steppe of Ukraine. Ukrainian Journal of Ecology, 8(4): 26-33. (in Ukraine).

Mazur, V.A., Mazur, K.V., Pantsyreva, H.V., Alekseev, O.O. (2018). Ecological and economic evaluation of varietal resources Lupinus albus L. in Ukraine. Ukrainian Journal of Ecology, 8(4), 148-153 (in Ukraine).

Mazur, V.A., Mazur, K.V., Pantsyreva, H.V. (2019). Influence of the technological aspects growing on quality composition of seed white lupine (Lupinus albus L.) in the Forest Steppe of Ukraine. Ukrainian Journal of Ecology, 9(1), 50-55. 
Mazur, V.A. (2018). Primary introduction assessment of decorative species of the lupinus generation in Podillya. Scientific Bulletin of UNFU, 28(7), 40-43. https://doi.org/10.15421/40280708 (in Ukraine).

Mazur, V.A., Vdovenko, S.A., Pantsyreva, H.V., Palamarchuk, I.I. (2018). Effectiveness of the application of soil milling in the growing of the squash (Cucurbita pepo var. giraumontia) in the right-benk forest stepp of Ukraine. Ukrainian Journal of Ecology, $8(4), 1-5$.

Methodology of economic and energy appraisal of types of fruit-bearing plantations, pomological sorts and results of technological research in horticulture/Ed. O.M. Shestopal. K.: Institute of Horticulture of UAAS, 2002. - 133 p.

Kashin V.I. (1995). Scientific fundamentals of adaptive horticulture/V.I. Kashin // M .: Kolos., 335c.

Pantsyreva, H.V. (2019). Morphological and ecological-biological evaluation of the decorative species of the genus Lupinus L.. Ukrainian Journal of Ecology, 9(3), 74-77.

Dospekhov B.A. (1985). Field experiment technique/B.A. Dospekhov - Moscow: Agropromizdat, 35 p.

Bounous D. (1986). Come e dove coltivarli mi nostril ambenti/D. Bounous // Jerra e vita. 26. P. 36-47.

Banshy S. (1986). Niehtore zahranicne shusenosti z pestovania malin/S. Banshy // Zahradnictvo, 11. 397 p.

Yaroslavtsev V.I. (2003). Raspberry and Blackberry/V.I. Yaroslavtsev - Moscow: Publishing House of SMEs, 144 C.

\section{Citation:}

Pantsyreva, H.V., Myalkovsky, R.O., Yasinetska, I.A., Prokopchuk V.M. (2020). Productivity and economical appraisal of growing raspberry according to substrate for mulching under the conditions of podilia area in Ukraine. Ukrainian Journal of Ecology, 10(1), 210-214. 